Гордана Арсић Комљеновић ${ }^{1}$, Јелена Кенић ${ }^{2}$, Драган Микић ${ }^{3}$, Христо Анђелски ${ }^{4}$

\title{
+Gz ACCELERATION AND OXIDATIVE STRESS
}

Gordana Arsić Komljenović, Jelena Kenić, Dragan Mikić, Hristo Anđelski

\section{Сажетак}

Биодинамички стрес изазван позитивним $(+G z)$ убрзањем по свом облику је краткотрајан акутни стрес, који се најчешће јавља код пилота борбене авијачије. Из литературе је познато да је позитивно $\mathrm{Gz}$ убрзаюе значајан стрес за основне физиолошке механизме, пре свега за кардиоваскуларни и респираторни систем.

Циљ: Ово истраживање првенствено је тражило одговоре у ком интензитету позитивно Gz убрзање може индуковати оксидативни стрес у виталним органима, првенствено јетри.

Материјал и метод: Експеримент на животиьама које су подељене у две експерименталне групе: I група (здраве животиње које нису третиране (ОО) и II група животиње које су биле изложене биодинамичком стрес моделу + Gz убрзања $(O G)$. Одређиване су активности ензима у jempu.

Резултати рада: Дејство биодинамичког стреса изазваног позитивним $(+G z)$ убрзањем довело је до промена активности појединих антиоксидантних ензима у јетри код (OG) групе животиња које нису биле третиране супстанцом (екстракт маточине, алкохол).

\section{Summary}

Biodynamic stress caused by the positive $(+\mathrm{Gz})$ acceleration in its form is a shortterm acute stress, which is most common in pilots of combat aviation. From the literature it is known that positive $G z$ acceleration considerable stress on the basic physiological mechanisms, primarily for cardiovascular and respiratory systems.

Objective: This study primarily sought answers in which the intensity of positive $G z$ acceleration may induce oxidative stress in vital organs, especially the liver.

Materials and Methods: The experiment on animals were divided into experimental group II: group I (healthy animals that were not treated (OO) and group II animals that were exposed to stress biodynamic model + $\mathrm{Gz}$ acceleration (OG). Enzyme activities were determined in the liver.

Results: The effect of biodynamic stress caused by the positive $(+G z)$ acceleration led to a change in the activity of some antioxidant enzymes in the liver of (OG) group of animals that were not treated with substances (extract Matochina, alcohol).

Keywords: positive acceleration, stress.

Кључне речи: Позитивно убрзање, стрес.

\footnotetext{
' Др сц. мед. Гордана Арсић Комљеновић, Висока медицинска школа струковних студија “Милутин Миланковић”, Београд.

2 Мр сц. мед. Јелена Кенић, "Richter Gedon“, Beograd.

3 Др сц. мед. Драган Микић, Војномедицинска академија, Београд.

${ }^{4}$ Др сц. мед. Христо Анђелски, Висока медицинска школа струковних студија “Милутин Миланковић”, Београд.
} 


\section{УВОД}

И

спитивања биодинамског ефекта на организам људи у значајној мери су усмерена ка проучавању утицаја смањене гравитације или хипергравитације. Прва истраживања се раде у циљу освајања космоса, а друга ради постизања превласти у ваздухопловној борби.

Луј Блерио (Louis Bleriot) je 1922. године написао “није отпорност материјала та која одређује границу акробатских могућности вештачке птице, него је то управо физиолошка отпорност човека, који је њен мозак".

Позитивно Gz убрзање је јединствени стресогени фактор летења који доводи до промена у свим органским системима. Стимулуси који започињу серију патофизиолошких збивања су, са једне стране, последица директног ефекта убрзања на смањење протока крви у мозгу, а са друге стране резултат покретања типичних „стрес“ реакција у склопу класичног адаптационог синдрома организма на било коју ноксу која ремети хомеостазу. Познато је да се у почетку организам прилагођава и брани од различитих нокси, самим тим и стреса. За оксидативни стрес се може рећи да је нормална појава присутна и код здравих особа. У нормалном молекулу језгро је окружено паром негативно наелектрисаних електрона. Процесом оксидације, уклањањем једног електрона из пара, молекул постаје „радикал“ - нестабилан и деструктиван, који напада суседне биомолекуле у средини у којој се нађе, тако да његовим деловањем долази до стварања нових слободних радикала ланчаном реакцијом. ${ }^{[1]}$ Процес оксидације је део регулаторног биохемијског функционисања наших тела у процесу стварања енергије која нам је неопходна за живот. Један од парадокса живота на планети је да молекул кисеоника који одржава у животу аеробне организме, није само основа енергетског метаболизма и процеса респирације, већ је одговоран и за настанак многих обољења и дегенеративних стања. Оксидативни стрес подразумева оштећење ткива које настаје због прекомерне производње слободних кисеоничних и других радикала, или њихове поремећене елиминације. ${ }^{[2]}$

Делимично редуковани облици кисеоника имају улогу у настанку великог броја различитих поремећаја код човека, као што су старење, канцер, неуродегенеративне болести и друге. Проблем настаје када се поремети фина равнотежа и када откажу природни механизми одбране, па ниво слободних радикала почне да превазилази капацитет организма да их неутралише, што мења оксидативни статус и тело улази у зону повећаног оксидативног стреса, или стање високог ризика за настајање најразличитијих поремећаја и болести. Штетно дејство слободних радикала у оксидативном стресу, према схватању савремене медицине, огледа се у настанку многих акутних и хроничних болести које се клинички манифестују као акутни и хронични запаљенски процеси (реуматоидни артритис, васкулитис), неуролошки поремећаји (Алцхајмерова болест, Паркинсонова болест, цереброваскуларна оштећења, мишићна дистрофија), кардиоваскуларни поремећаји (хипертензија и хипертензивна болест срца, атеросклероза), фиброза плућа, катаракта, малигне болести, али и многа друга стања која се називају прерано старење. ${ }^{[3]}$

\section{ЦИЉ РАДА}

Знајући из литературе да је позитивно Gz убрзање значајан стрес за основне физиолошке механизме, пре свега за кардиоваскуларни и респираторни систем, ово истраживање првенствено је тражило одговоре у ком интензитету позитивно $\mathrm{Gz}$ убрзање може индуковати оксидативни стрес у виталним органима, првенствено јетри. Оксидативни стрес може бити иницијални и базични окидач у оштећењу ћелије и ткива, па би утврђивање агресивних и откривање протективних супстанци значајно допринело побољшању статуса особа које су му често изложене. 


\section{МЕТОДОЛОГИЈА ИСТРАЖИВАЫА}

Експеримент на животињама које су подељене у две групе, а у свакој групи је било 10 животиња:

- I група (контролна): здраве животиње које нису третиране (ОO);

- II група: животиње које су биле изложене биодинамичком стрес моделу $+\mathrm{Gz}$ убрзања (OG).

\section{Параметри испитивања}

Одређивање активности ензима у јетри:

- Садржај редукованог глутатиона (GSH) по методи Капетановића и Mieyal-a (1979);

- Активност пероксидазе (Рх) одређивана је методом Симона и сар. (1974);

- Активност каталазе (САТ) одређивана је методом Beers-a и Sizer-a (1950);

- Активност глутатион пероксидазе (GSH-Px) методом по Chin-у и сар. (1976);

- Активност ксантиноксидазе (XOD) методом по BergMayer-u (1976);

- Интензитет липидне пероксидације (LPx) одређиван је по методи Bueg-a и Austa (1988);

- FRAP(Фериредуктазна антиоксидантна активност) по методи Benzie-a и Strain-a (1999);

- Макроскопске промене на јетри и слузници желуца;

- Микроскопске (патохистолошке) промене у ткиву јетре, срца и слузнице желуца.

\section{РЕЗУЛТАТИ РАДА}

Дејство биодинамичког стреса изазваног позитивним $(+\mathrm{Gz})$ убрзањем довело је до промена активности појединих антиоксидантних ензима у јетри код (OG) групе животиња које нису биле третиране супстанцом (екстракт маточине, алкохол).
Интензитет Lpx се статистички значајно смањио ( $<<0.05)$, активност САТ је била статистички значајно повећана $(\mathrm{p}<0.01)$ и активност GSHPx била је статистички значајно повећана $(\mathrm{p}<0.01)$. Активност XOD се није значајно мењала, садржај GSH је био смањен, активност Рх је била повећана, али не статистички значајно, у односу на нетретиране животиње (ОО група)

Биодинамички стрес изазван позитивним $(+\mathrm{Gz})$ убрзањем је код испитиваних животиња OG групе изазвао значајне промене активности појединих антиоксидантних ензима (Графикон 1).

Графикон 1. Промене параметара оксидативног стреса у јетри животиња $O G$ групе излагане позитивном (+7Gz) убрзању (активност XOD, CAT, Px, GSHPx изражена y nmol/mg протеина $\cdot \mathrm{min}^{-1}$; интензитет Lpx изражен у пто малондиалдехида/mg протеина; садржај GSH изражен у птоl GSH/ mg протеина).

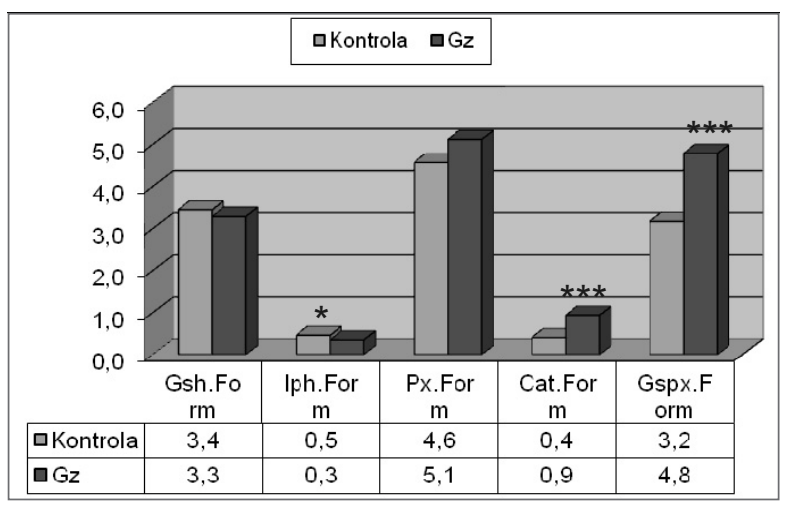

Интензитет Lpx се статистички значајно смањио $(\mathrm{p}<0.05)$, активност САТ је била статистички значајно повећана $(\mathrm{p}<0.01)$ и активност GSHPx била је статистички значајно повећана $(\mathrm{p}<0.01)$. Активност XOD се није значајно мењала, садржај GSH је био смањен, активност Рх је била повећана, али не статистички значајно, у односу на нетретиране животиње (OO) група. 
Графикон 2. Антиоксидативни потенцијал у јетри, одређен FRAP metodom.

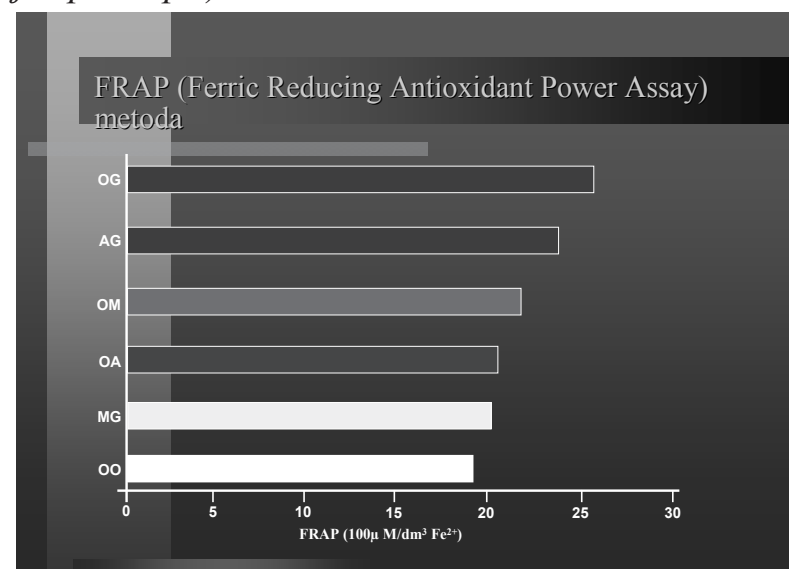

ДИСКУСИЈА

Према познатим подацима из литературе, велика позитивна $\mathrm{Gz}$ убрзања (од $+5 \mathrm{Gz}$ до $+20 \mathrm{Gz}$ ) проузрокују видљиве промене, на структурама срчаног мишића, доводе до едема миокардијалних и ендотелних ћелија срчаног мишића. ${ }^{[4]}$

Досадашња истраживања су показала да нагло позитивно Gz убрзање, као снажан стресогени фактор летења, доводи до активације неуроендокриног система ${ }^{[5]}$ и следственог пораста симпато-адреналне активности $^{[6],[7]}$, повећања секреције ренина ${ }^{[8]}$, вазопресина $^{[9],[8]}$, кортикостероида и других хормона. ${ }^{[5]}$

Постоји много елемената који повезују активацију имунског система и оксидативни метаболизам. А клинички елемент ове везе су: анемија у хроничним болестима, нисходна регулација оксидативног метаболизма и дисфункција имунског система у синдрому хроничног умора, уклањање гвожђа у току хроничних инфламација др. ${ }^{[13]}$

Урађене су многе студије у којима је праћен оксидативни стрес и оштећење ткива јетре пацова при исхемији-реперфузији. Група истраживача је урадила студију и доказала да је након 180 минута исхемије, активност XOD порасла за 26\%, док се активност SOD, CAT, GSHPx није мењала. Након реперфузије уочен је значајан пораст продукције оксирадикала и оштећења ткива. Истовремено је уочена смањена активност SOD, CAT, GSHPx. ${ }^{[13]}$
Неутрофили пак продукују супероксид анјон радикал $\left(\mathrm{O}_{2}{ }^{--}\right)$, који припада групи реактивних кисеоничних врста (ROS). ${ }^{[12]}$ Поред супероксид анјон радикала, истиче се и велики значај хидроксил радикала $\left(\mathrm{OH}^{*}\right)$ у развоју стрес улкуса. Наведене ROS реагују са липидима ћелијских мембрана, изазивајући липидну пероксидацију (Lpx), долази до ланчане реакције и може доћи до смрти ћелије. ${ }^{[15],[16]}$ Против наведених реакција оксидативног стреса, који се сматра најодговорнијим за настанак стрес улкуса, организам се брани постојећим системом антиоксидантних ензима, и то SOD, CAT, Px, GSHPx, GSHR и XOD која је, у ствари, прооксидантни ензим у великом броју случајева, али и неензимским антиоксидантним једињењима, а пре свих GSH-ом.

Као што смо већ напоменули, организам се брани антистресном реакцијом, продукцијом различитих супстанција: хормона, ензима и других антиоксиданаса, који имају заштитну улогу, са циљем да одрже хомеостазу у организму. Основна улога ових механизама је да смање количину и неконтролисано стварање ROS-a и њихових прекурсора у ћелији. Механизми заштите се разликују, али сви делују хармонично и синхронизовано.

Одређене супстанце имају способност да неензимским путем реагују са слободним радикалима преводећи их у стабилне молекуле мале реактивности, спречавајући тако штетне ефекте ових високореактивних честица. Једна од њих је и азот-моноксид.

Улогаазот-моноксидаједобро објашњена у оксидативном стресу. Анализа улоге азотмоноксида указује на две могуће функције. Повећана продукција NO од стране макрофага и других ефекторних ћелија имуног система истиче пре свега његову одбрамбену улогу, односно доминантну улогу у регулацији имунолошког одговора. С друге стране, синтеза NO у ендотелијалним ћелијама и неуронима указује на улогу NO у трансдукцији сигнала. Фини физиолошки баланс између ове две супротне физиолошке 
функције NO (уништавање страних ћелија и провођења сигнала у ћелије) зависи од продукције других реактивних врста кисеоника (ROS).

У испитаника, кандидата за Ваздухопловну војну академију, позитивно Гз убрзање је у првих 45 минута довело до смањења продукције NO на основу одређивања концентрације нитрита/нитрата у серуму и повећања концентрације солубилног Р-селектина у плазми. ${ }^{[13]}$ До сада у литератури нису објављени подаци о изучавању NO након акцелерацијског стреса, па је у том контексту тешко поредити ове резултате. Међутим, у литератури постоје бројни подаци о промени продукције NO у току различитих врста стреса. У стресу изазваном фиксацијом животиња, форсираним пливањем, излагањем хладаноћи или топлоти у току адаптације забележена је повишена продукција NO.

Према најновијим сазнањима, оксидативни стрес, тј. слободни радикали имају значајну улогу у патогенези преко 100 обољења, почев од стрес улкуса, преко реуматоидног артритиса, хеморагичног шока, стечене имунодефицијенције, па до процеса старења. ${ }^{[14]}$

Као што је већ више пута поновљено позитивно Gz убрзање је јединствени стресогени фактор летења који доводи до промена у многим системима, и промена на целуларном нивоу, карактеристичним за акутни стрес.

Наши резултати указују на значај оксидативног стреса изазваног позитивним Gz убрзањем, кроз промене вредности параметара оксидативног стреса у јетри.

Код експерименталних животиња (OG) које су излагане дејству позитивног $\mathrm{Gz}$ убрзања, позитивно Gz убрзање изазвало је значајне промене активности појединих антиоксидантних ензима у јетри у односу на животиње које нису излагане позитивном Gz убрзању (OO). Интензитет Lpx се статистички значајно смањио ( $<<0.05)$, активност САТ је била статистички значајно повећана $(\mathrm{p}<0.01)$ и активност GSHPx била је статистички значајно повећана $(\mathrm{p}<0.01)$. Активност XOD се није значајно мењала, садржај GSH је био смањен, активност Рx је била повећана, али не статистички значајно, у односу на нетретиране животиње (ОО група)

У јетри за време позитивног Gz стреса нису у току истраживања регистроване лезије, па сходно томе вероватно не долази до нагомилавања неутрофила као код желуца, те је превага САТ активности већа. Вероватно да се у току стрес улкуса ослобађају супероксид анјон радикал $\left(\mathrm{O}_{2}{ }^{-}\right)$, хидроксил радикал $\left(\mathrm{OH}^{\cdot}\right)$ и водоник пероксид $\left(\mathrm{H}_{2} \mathrm{O}_{2}\right)$, јер САТ заједно са осталим ензимима учествује у њиховој разградњи.

У току еволуције дошло је до стварања комплексних механизама заштите од оксидативних оштећења. Основна улога ових механизама је да смање количину и неконтролисано стварање ROS-a и њихових прекурсора у ћелији. Механизми заштите се разликују, али сви делују хармонично и синхронизовано. Најзначајнији ензими од оксидативних оштећења су: супероксиддисмутаза (SOD), каталаза (CAT), пероксидаза (Рx), глутатион-пероксидаза (GSHPx), глутатион-редуктаза (GSHR), глутатион S-трансфераза (GST) и др.

Подаци из литературе разликују се од аутора до аутора. Доста су разнолики у погледу повећања или смањења активности појединих антиоксидантних ензима. Тако, неки наводе повећање активност SOD, CAT и Рx у стресу, а неки смањење. ${ }^{[14],[15]}$

У савременој литератури нема доступних радова о истовременом утицају оксидативног стреса и позитивног Gz убрзања на функцију јетре праћене кроз промене активности појединих антиоксидантних ензима. Зато су наши подаци оригинални и неупоредиви, и то даје могућности за даља истраживања утицаја позитивног $\mathrm{Gz}$ убрзања на функцију јетре и параметре оксидативног стреса: 
- Испитати утицај $+\mathrm{Gz}$ убрзања на активност ензима CAT, Px, GSH-Px, $\mathrm{XOD}$, укупан садржај GSH и интензитет LPx y јетри мишићу и на слузници желуца;

- Испитати утицај +Gz убрзања на патохистолошке промене у јетри, срчаном мишићу и на слузници желуца;

- Одредити укупан антиоксидантни статус у јетри свих група испитиваних животиња FRAP методом.

\section{ЗАКЈУЧЦИ}

Биодинамички стрес изазван $+7 \mathrm{Gz}$ убрзањем (прираст $0.1 \mathrm{G} / \mathrm{s}$, укупно трајање стреса 3 min: 40sec. max оптерећење) довео је до:

а. значајних промена параметара оксидативног стреса у јетри:

- повећања активности каталазе (САТ);

- повећања активности глутатон пероксидазе (GSH-Px);

- смањења интензитета липидне пероксидације (LPx)

б. патохистолошких промена у јетри:

- нејасне ћелијске границе;

- вакуолизованог ткива;

- агрегације тромбоцита у крвним судовима.

\section{ЛИТЕРАТУРА}

1. Живковић $\mathrm{M}$, издавач. Хипербарична и подводна медицина. Београд: НВО medical center; Наука, 1998, 251 стр. $\mathrm{ID}=55440652$

2. Ganong WF. Review of Medical Physiology. 2005. McGraw-Hill, Изд. Савремена администрација, Београд, 520-521.

3. Hoyt A, Luukkonen J, Juutilainen J, Naarala J. (2008) Title Proliferation, Oxidative Stress and Cell Death in Cells Exposed to $872 \mathrm{MHz}$ Radiofrequency Radiation and Oxidants. Journal Radiat Res. 170(2): 235-243.

4. Benni PB, Li JK, Chen B,, Cammarota J, Amory DW. Corelation of NIRS determined cerebral oxigenation with severity of pilot $+\mathrm{Gz}$ acceleration symptoms. Adv Exp Med Biol. 2003; 530: 381-389.

5. Mills FJ, Marks V. Human endocrine response to acceleration stress. Aviat. Space Environ. Med.1985; 53: 537-40.
6. Krahenbuhl GS, Marett JR, King NW. Cateholamine exertion in T-37 flight training. Aviat. Space Environ. Med. 1977; 48: 405-8.

7. Kaciuba-Uscilko H, Smoravinski J,, Nazar K, Adrijan J, Greenleaf JE. Cateholamine responses to environmental stressors in trained and untrained men after 3-day bed rest. Aviat. Space Environ. Med. 2003; 74: 928-36.

8. Rogge JD, Fasola AF, Martz BL. Periferal venouse rennin levels during $+\mathrm{Gz}$ acceleration. Aerosp. Med. 1967; 38: 1024-8.

9. Keil LC, Ellis S. Plasma vasopressin and rennin activity in women exposed to bed rest and $+\mathrm{Gz}$ acceleration. J Appl. Physiol, 1976; 40: 911-4.

10. Kwiecien S., Brzozowski T., Konturek SJ. Efffects of reactive oxygen species action on gastric mucosa in various models of mucosal injury. Journal of Physiology and Pharmacology. 2002; 53(1): 39-50. 
11. Das SK., Vasudevan DM. Protective effects of silymarin, a milk thistle (Silybium marianum) derivative on ethanol-induced oxidative stress in liver. Indian J Biochem Biphys. 2006 Oct; 43(5): 306-11.

12. Sairam K, Rao ChV, Dora Babu M, Vijay Kumar K, Agrawal VK, Goel RK. Antiulcerogenic effect of Methanolic extract of Emblica officinalis: an experimental study. Journal of Ethnopharmacology. 2002; 82: 1-9.

13. Комљеновић Г. Утицај $+\mathrm{Gz}$ убрзања на неуроендокрини и имунски одговор.
Докторска дисертација, Војномедицинска академија, Београд, 2007.

14. Niki E., Yoshida Y., Saito Y., Noguchi N. Lipid peroxidation: Mehanisms, inhibition and biological effects. Biochem and Biophys Res Co-mmun. 2005; 338: 668-676.

15. Kwiecien S., Brzozowski T., Konturek SJ. Efffects of reactive oxygen species action on gastric mucosa in various models of mucosal injury. Journal of Physiology and Pharmacology. 2002; 53(1): 39-50.

Контакт: Др сц. мед. Гордана Арсић Комљеновић, Висока медицинска школа струковних студија “Милутин Миланковић”, Београд. 